\title{
Pathological Analysis of the Charter of Citizenship Rights in Iran in Judicial Rights Terms with a Focus on Human Dignity
}

\author{
Fatemeh Piraman ${ }^{1}$, Seyed Mohammad Sadegh Ahmadi $^{1} \&$ Masoud Raei $^{1}$ \\ ${ }^{1}$ Department of law, Islamic Azad University, Najafabad Branch, Najafabad, Iran \\ Correspondence: Seyed Mohammad Sadegh Ahmadi, Department of law, Islamic Azad University, Najafabad \\ Branch, Najafabad, Iran. E-mail: piramanf@yahoo.com
}

Received: September 4, 2016

Accepted: October 2, 2016 Online Published: December 29, 2016

doi:10.5539/jpl.v10n1p177

URL: http://dx.doi.org/10.5539/jpl.v10n1p177

\begin{abstract}
Judicial right is one of the most significant fields of citizenship rights. A large part of the right legal instances become considerable when a citizen is under suspicion. To codify the examples of legal rights principally, the concept of human dignity needs to be the focal point on a constant basis. In the case of ignoring this criterion in arranging the constitutional rights the justice would not be attained, and the legal security of the citizens would be disrupted.

Within the constitutional rights of Iran, the charter of the citizenship rights as a comprehensive document considered within the constitutional right field. In the preface and principles of this document human dignity is confirmed as one of the most significant factors in codifying the citizenship rights. However, in the continuation and in the arrangement of the instances of the citizenship rights this criterion has not been considered as expected.

The charter of the constitutional rights compared to previous rules of it has no significant innovation. Two groups of factors have caused the insignificant role of human dignity within the judicial rights. The first groups include the general factors such as presenting an inaccurate definition of citizen and mingling the instances of human rights with examples of rights. The second group of factors that mostly relate the lack of precise positioning towards some of the accepted principles of the legal right has provided the possibility of violating human dignity in this charter.
\end{abstract}

Keywords: judicial rights, human dignity, citizenship, citizenship rights, citizenship rights charter

\section{Introduction}

Judicial rights as a set of rules that guarantee the citizenship rights in legal affairs at various levels include one of the most significant parts of the citizenship rights. The human dignity requires this principle to be implemented for all citizens of the society, and the legal compound predicted under this title does not belong to a particular part of the citizens. But it should be considered that principally in all instances of the legal rights the implication of the law happens when there has been a crime. Penal policy, legislation, particularly regarding the way of verification of the case, should be arranged in a way to respect the human dignity principle at all levels and for all citizens.

Although today one of the most significant areas of the judicial rights which are internationally emphasized refer to the way of verification of the cases (Razavi and Seyyed Khazaie, 2010). But the totality of the legal rights is not limited to this issue and other instances, such as litigation and the reference to the judicial authorities or the right of not imposing violent punishments are also included. In the instances above, the concept of human dignity can also be presented as a reliable and constant criterion.

Today it is approved that observing citizenship rights optimally require the codification of a comprehensive set in this respect. At the present era because of the rise of the social communication and particularly given the increase in the literacy and the ability of people the presence of an underlying document under the title of citizenship rights charter whose contents can be inferred as the primary principles of the citizenship rights. In addition to leaving an opposite impact on guaranteeing the observation of the citizenship rights of the states, it would also have a significant impact on the general ability of the public in fulfilling their rights in human communities (Pur Ezzat et al., 2008). This issue has more conspicuity within judicial rights field where lack of 
observing leads to the violation of the justice at the society level whose compensation is practically impossible.

Charter is a written statement of the certain group rights that is an agreement that is arranged by a person or a group of individuals by what the relationships and mutual rights of a social structure such as a University or city formed (Short Oxford English Dictionary, 2002, 751). Accordingly, the charter of the citizenship rights is a statement which is written, defines the respective rights of the citizens, analyzes the implementation structures and finally leads to its support. To attain this significant issue, the intended rights need to be clear and without ambiguity fulfilled and precisely determine the member organizations and foundations. Usually, the benefits obtained from the codification of the charter returns to all members of the society, but the poor and the susceptible class of the community advantages in a particular way (Pollitt, 1994, 21). As a result, the charter of the citizenship rights can be implemented as a practical means of unifying the citizens regarding the rights and responsibilities.

The citizenship rights generally and the legal rights as part of it lacks the legislative background at various levels of the legislation of Iran. However, the absence of the reference to the citizenship right subject by the constitution and also the expansion of this concept over the time made the legislator codify the fourth development program law with rectifying the article 100 make the state responsible for encoding and passing the full charter regarding the citizenship right. From fourth development program vantage point, this issue was so important that by the part $\mathrm{h}$ of the article 130 of the law above the judiciary power is responsible for preparing and arranging and codifying the bill of improving the citizenship right.

By the codification of the fourth development program, the necessity of the codification of the citizenship right became visibly significant. In other words, besides the social needs and legislative responsibility became part of the state responsibilities. However, by unjustified delay, the charter of the citizenship right was arranged and codifies by the legal deputy of the president in 2013. One of the most significant issues mentioned in this letter was the charter of the judicial rights of the citizens. This study with a pathological view tries to answer this question that has the charter been dignity-oriented in the legal rights' field? The answer to this question would include the weak points of the charter in this respect, particularly regarding the human dignity.

\section{Judicial Rights Concept}

The citizenship right has different fields such as civil, social and cultural rights. These areas, principally of great significance and include a broad range of issues so that some in defining the citizenship right refer to the corresponding areas (Mohseni, 2007, 160). The expansion of the citizenship rights in any field gradually leads to the formation of new areas. For example, the expansion of the citizenship rights in the field of employment and the economy has led to the classification of economic rights which used to be part of the social rights in the past (Hezar Jaribi and Safari Shali, 2010,158).

Judicial right is one of the most basic fields of the citizenship rights that the fulfillment of the legal security depends on the recorded principles in it. The right of access to the legal system, innocence principle, no retrospection of the rules, the legal principle of the crimes and punishments, the principle of preventing wayward arrest and illegal and the open trials are the laws that guarantee the citizenship rights. By this description legal security refers to a state in which the honor, life, property and all material and spiritual affairs of the human supported by the law and the judiciary power (Hashemi, 2005, 276).

Today each of the principles above has their subsection and branches that sometimes the observation of them is as important as the principle itself. For example, the independence of the judge and court, defense, fair trial, the right of objection to the judgment of the magistrate, access to the legal reasons, making compensation for legal mistakes, selecting the lawyer, are the instances of the legal rights that can be presented as a plan today.

As it is evident legal rights, principally belong to all citizens, not a particular part of the society. Human dignity also requires this rule to be applied to all members of the community. However, given the nature of the legal rights occur when a citizen suspected of committing a crime. The criminal policy of the society in codifying the rules, in particular, the penal standards and especially rules related to the way of conducting trials should be arranged in a way that respects the human dignity and the citizenship rights.

The Criminal trial Regulation should be codified in a way that by the prediction of the legal and regulatory organizations equipped and combined of various experts either legal or criminal by differentiating the eligibility of each of them and creating the necessary provisions and requirements in trials and defense of the sides and make the proper justice possible. It is evident that to preserve the benefits of the society the rights and interests should not be sacrificed. Because if the judgment calls for the punishment of the real criminal the condition of the administration of justice requires this very criminal have the right to have a chance to defend himself 
(Madani, 2001, 4). In fact, the rules related to the constitutional rights (especially the penal trial regulation) would have the sufficient value and credit when it can establish a balance between two rights. That is the right of society which has suffered the crime and on the other hand the human right that is for the time being known as suspect (Ashuri, 1990, 37).

The fulfillment of the principle purposes of the penal law is a form established against the felony and protecting the public order of the society (Tayyebi, 1999, 78) requires the detection of the crime, pursuing analyzing and finally a trial by legal justice and observing the ruling principles of the human dignity. Discovering the crimes and at the same time preventing the damage to the citizenship rights of the suspects and also preserving the honor and dignity of the honest and righteous people and preventing the unlawful judgments all are in a relationship with the local and international order of the society (Razavi and Seyyed Khazaie, 2010). In fact, from the first step, the measures were taken by the judicial archivists to discover the crime the penal justice wheel starts moving that by the law (Akhundi, 2001, 53). Also, by the use of the scientific methods of discovering the crime instead of the traditional methods (Etedal, 1998, 73) and in other stages the judicial officials observe the accepted principles.

Today the rules of the penal trial regulations in many of the countries of the world are under fundamental changes and corrections. These changes are mainly in accord with the ruling principles of testing rules and observing the citizenship rights of the culprits. Although the factors that lead to this change of the legal system are many, there is a common goal in all of them that is the combination of the citizenship rights to what the efficient penal justice requires. In implementing this goal, the type of the crime has no impact (Ashuri, 1990, 143). This issue has also been attended in Iran so that the legislator in 2004, by codifying a single article shows respect to the legal freedom and the preservation of the citizenship rights and focusing mostly on the stage of discovering the crime. And the primary analyses and the emphasis of the judicial system of the country to observe the rights of the suspect and the law during the discovery and pursuit and in particular inquiry and research stages (Hashemi Shahrudi, 2007, 54). In continuation by the codification of the penal trial regulations in 2013 that was followed by some corrections and appendixes in 2015 took significant steps towards the fulfillment of these goals.

Although the majority of the principles and rules predicted in judicial rights is oriented towards penal rights, but it should be considered that they are not totally directed towards penal issues. The right of the access to the worthy judicial system refers to the provision of the right to trial and reference to the judicial authorities to attain their rights either that case is legal or penal. The struggle between the processes of the principle is the verification of the private in criminal cases.

In addition to the aforementioned issues today, many of the regional and international documents and also the legal systems of many countries the right of not inflicting incongruent punishment for a human has been accepted as a fundamental principle of the citizenship rights. Considering the local rules of other countries show that the right of freedom from torture and cruel or humiliating punishments until 1993 were codified in different countries and other countries are also joining this list (Dirk Van and Ashworth, 2004, 543). Some of the constitutional rules have not predicted such an explicit right, but they can be interpreted as considering this right. For example, the human dignity in the constitution of Germany and Nigeria has been explained in a way that includes the forbiddance of cruel and inhumane and humiliating and inapposite punishments (NnamaniOgbu, $2005,174)$. The position of discussing this right that directly originates from the intrinsic dignity and honor of human and even committing a crime is not an admissible excuse to violate this right belongs to the citizenship legal rights.

\section{Citizen and Human Dignity within the Citizenship Rights Charter of Iran}

\subsection{Citizen from Charter's Vantage Point}

The charter of citizenship rights of Iran has not presented a definition of citizen. That has caused the inclusion of those within this circle to be unknown. It is not clear who are the subject of the citizenship rights, within the charter. In part 1 of the article, 2 of the charter the discussion of the human dignity is presented as the influential factor on the human dignity. If this criterion is accepted anyone, regardless of the acquisitive features is considered as the rightful. But in spite of that just at the beginning of the charter note, there is a reference to all nationalities of Iran that is the human dignity is replaced with the citizenship concept.

In the instances of the citizenship rights and in places where the charter tries to determine the persons on the subject the interference of the citizenship concept is quite evident. The entrance of the idea of a citizen by the codifier of the charter is a certain issue, and this is one of the primary criticisms against the charter of the citizenship rights. The origin of the differences originates from the ruling criteria on the concept of the 
citizenship rights. The idea of the citizenship rights at social dimension was the idea presented in the sixteenth century in the Western Europe and seventeenth century distributed and all in all it can be considered as a new concept (Hashemiyan Far and Ganji, 2007, 44). But despite that, there is a difference of opinion regarding the determining criteria.

Some believe that citizen is part of the human group whose members are joined because of the material and spiritual reasons to each other and feel dependent to the community and consider themselves of the same fate the same as the members of the group (Ghazi Shariat Panahi, 1996, 56). In the same line of thought, it has been stated that citizenship is the reflection of the relationship between individual and the society within the framework of right and responsibility (Falks, 2002, 15). By this perspective, the value of the citizenship lie on two issues: one is the place of birth and the other is the nationality of the mother and father (Ashuri, 1990, 222). As it is evident, the concept of citizenship originates from an external concept beyond the human origin. Some consider this external factor as the political, legal and spiritual relationship of the individual with the government (Azar dad 2010, 12) or the related nationality or the citizenship the same as nationality (Kamyar 2000, 26). Some others relate this concept with nationality and consider the concept of the city in citizenship the same as a nation (Madaniyan, 2011; Miller, 2004). Accordingly the definition of the citizenship either at nationality or allegiance can be reflected and as a result, the outside groups would be avoided from the citizenship rights.

In another vantage point instead of saying that humans are divided into two groups of relative and non-relative and only the parents are the citizens who benefit from the citizenship rights and human become the basis of benefiting from the citizenship rights. In this view, all members of the society enjoy the political right and the citizens are divided into two groups of Allegiant and not Allegiant (Pallu 1991, 218). In fact, the lack of justification concerning the provision of the citizenship rights for non-national members of the society of the political rights in this categorization refers to their lack of political responsibility in that country. In later view, the position of human dignity and the provision of this right of the members of the society appear more conspicuous. This view has led to the new interpretation and a more general concept of the citizenship rights. In this view benefiting from the citizenship rights by the world personality and the world, not by the national belonging (Falks, 2002, 173).

Although the charter has pretended to observe the human dignity criterion, it seems that in the first step that is the definition of the citizenship rights is equal to the definition of allegiance. Certainly, under this condition those who live in Iran and our country by the international rules has accepted their rights are in practice accepted the same as the hostages are bereft of the rights of the citizenship rights. Even the definition of the quasi-citizen a concept that is based on residing and by the purpose of non-residents created in political rights (Kastelz and Davidson, 2003, 189-210) have not been confirmed.

\subsection{Human Dignity within the Charter}

The concept of the "human dignity" in legal literature is a newly emerged concept. But this newness does not mean that there is no background to this concept. This conceptually the same as other subjective views originate from the old schools and religion, middle ages and the modern era. But in spite of that the Renaissance period is allotted a practical meaning to it (Aramesh, 2011, 48). So that today it is known as the ideal concept of the human rights. The human dignity explicitly used in the charter, and it seems that the codifiers of the charter intend to use this concept as the principal basis of the arrangement of the citizenship rights although there is no loyalty in practice to this idea.

The term Keramat (dignity) is derived from the Arabic language and in the Persian language it used with the respect, reverence, and honor (Eben manzur, 1983; Farahidi, 1988). The Persian terminology defines dignity as $<$ value, reverence, honor, prestige, degree, rank, position, humanity, place, free from humble and free from impurity, generosity, and magnificence and chivalry $>$ (Dehkhoda, 1998). Also < gratitude, magnanimity, courage, pride, dignity, and honor $>$ (Moin, 2009, 854) in the English language the expression, dignity is determined from the Latin word $<$ Dignitas $>$ and means righteousness, honor, and deserving reverence have been used (Short Oxford English Dictionary, 2002, 398).

There is a difference regarding the technical definition of the term human dignity. This difference originates from the basis on which the intellectuals have considered for this concept. The charter explicitly has confirmed the human dignity, but has not presented any definition of it. The point of the subject is that no definition of the human dignity has been submitted in any legal or international document. For the same reason, to understand its meaning, we need to refer to the views of the intellectuals.

In non-religious perspective, although human dignity represents the value and the honor that all humans intrinsically and equally have (Kant, 1956, 214) by its implementation there is a difference. Regarding the basis 
of the human dignity different schools have been formed. Some of the natural rights theory considers the foundation of the human dignity of the unitary nature of human. The followers of the natural right school believe that the certain rights that are the rights that originate from the nature of human being and was assumable before the formation of the government foundation (Katuzian, 2000, 17). They are superior, and fundamental rules that are above the will of the governments and the states are responsible for supporting them and observing them (Kinia, 1972; Shayegan, 1956). It should be considered that although the basis of these rights is the nature of human, the mind of the human usually confirms them and consider them in accord with the social nature of the person (Katuzian, 2006, V.1, 53). By this view, the benevolence of the human being is one of the essential requirements of a person, and wisdom rules for the fact that dignity is part of the human nature. Being from the very beginning has been created with the reverence and the benevolence special to him, and this reverence is part of its creation. Therefore this description is not separable from the human kind and certainly codifying the law against it would not be eligible. The main criticism against this mind-oriented view as the means of extracting and reducing natural rights and the possible controversies that may happen following accepted this basic return.

After natural right school, the individualism school is one of the main mental schools that has been very influential in the development and expansion of the human dignity concept (Rahimi Nejad, 1999, 34). In this view, the society lacks an independent existence because the identity of the society is not something apart from its members. Society is a group of people who have come together to reach a common goal. Human to reach the final goal of his that is the happiness needs to establish a society. Therefore the tendency of the human to build a society is because it is a means of reaching the happiness and the establishment of the society is not a goal (Abunasre farabi, 2002, 119). Some of the scholars, such as Jabez, Roso, Steward Mill believe in this opinion (Sadr, 2002, 109, 110). Max Weber has selected the same view in his social belief (Tavakkol, 2003, 482). On the other hand, other groups such as Herbert Spenser and his followers are against this view. Some other scholars have considered the presence of the society as critical for the human being to reach the ultimate perfection, and the final happiness, but they have not found independence for it (Akhavan Alsafa, 375). Against this school, great scholars such as Khaje Nasreddin Tusi (Khaje Nasreddin Tusi, 1984, 280), Eben Khaldun (Eben Khaldun, 72) and also Herbert Spenser Rene worm and Hegel (Hosseini Dashti, 2006, 613) believe in the socialism. Given the fact that in individualism theory the originality belongs to the individual the preservation of an individual's dignity against the violations of the society is necessary. In other words, it is the dignity of the person that is superior to anything else. Because of the expediency, we, can't ignore the human dignity. On the basis of this view respecting the human dignity in addition to providing the individual benefits and finally the requirements of the society is caused.

Some believe that the concept of human dignity is one of the ideas based on the ethical philosophy of Kant. Kant proves the freedom and autonomy of humanity through the moral rule and even considers liberty and the moral law as correlative (Kant, 1956, 127) Kant's view of the human dignity is opinion based on the individualism. In this notice, Human has an exceptional natural value that the benefits of the group cannot be prioritized over it (whatever the society). No human can be found bereft of value. All people are respectable because of the dignity that they have. Therefore, no human even the evil people cannot be disrespected although by doing wrong actions have made themselves without value (Ghari Seyyed Fatemi, 2003, 110). According to Kant, the value of a human is natural and the values such as skills and abilities show the position and condition of the person and do not reflect their value (Muhammad Rezaie, 2000, 112).

In Kant's view, any human should be considered as respectable, not because of the position that he holds. Therefore, in this opinion any action that feels personal as the ultimate goal and not the mere tool, it is an ethical action otherwise it is unethical (Ibid, 112). Kant's view of the human as the ultimate is small and appreciable viewable. But the weak point of this view is that the limitation of the human is not determined. In fact, the differentiating aspect of a person is somehow vague. Kant considers the responsibility and commitment of respect for the human dignity merely by the mentality (Ghari Seyyed Fatemi, 2003, 108).

Human dignity is also present in religions. Among them, the most specialized discussion is presented in Islam in this respect. In the Islamic view, the human dignity as an accepted principle is attended from two aspects. The dignity allotted to a person and the dignity attained by a person.

Acquisitive dignity is not related to the nature of the human, but it is achieved by the attempt made by the person. The unique feature of the human is the power of differentiating between good and evil and useful and harmful by the use of the eye, ear and heart (Musavi Hamadani 1996, 439). The required condition is to reach this goal and in an Islamic school, the purpose of natural dignity is a type of special dignity of a human being. That is the very concept that can be analyzed under the title of human dignity. Many Ayahs of Quran refer to the belief of Islam to this dignity for human being (Tabarsi, 1992, 666; Hosseini Shah Abdolazimi, 1987, 272; Makarem Shirazi, 
1997, 209).

However, it should be considered that the purpose of the human dignity in Islam is the natural dignity. When the purpose is the acquisitive dignity, the subject is clarified by some instances. Besides that concerning the concept of the greedy and natural dignity: human dignity within the field of law can only refer to the inherent dignity of the Islamic school.

Theoretically at the preface and general rules of the charter of the citizenship rights an opposite position has been considered for the human dignity. It seems that the meaning allotted to this concept is the same sense in a religious vantage point that is referred to under the title of natural dignity. But in practice and at a codifying section on the rights and determining the citizens the subject of this law the focus of the human dignity is diverted.

\section{Legal Rights within the Charter of the Citizenship Rights of Iran}

\subsection{Legal Rights within the Charter Compared with Other Present Rules}

One of the weak points of the charter regarding the instances of the citizenship rights is the lack of being bound to a particular framework and lack of observing reasonable order. That has caused unjustifiable irregularity regarding the cases of the citizenship rights. Fortunately, regarding the legal rights, the charter has predicted a particular chapter entitled legal justice under the notes of 85-93 of the article 3 has codified the instances of the legal rights. In other words, in the field of the legal rights, the codifiers of the charter have done their responsibility by assigning a separate part to the subject of the citizenship rights. It includes terms, the preserving the rights of the people and respecting the constitutional freedom of the citizens by codifying certain rules free from ambiguities (Shams Nateri and Attarzade, 2009). The penal legislation, policy of the Islamic Republic of Iran, even before the codification of the charter took significant measures to guarantee the observation of the legal citizenship rights and respecting the constitutional freedom that in spite of the presence of strength points can be criticized in some terms. The right of the lawsuit, the right of access to the competent court and the right of inviolability are the most fundamental rights that the Charter has predicted for all citizens. The right of defense at all legal authorities, fit and military the right of access to the lawyer of cases and the responsibility of the government to provide the requirements and facilities of this right for the citizens are among the righteous. It can be functional by the entrance of the citizens of a lawsuit, and this type of the rights have the legislative background before the codification of the charter. Principles 34 and 35 of the constitution have identified the principle of the access to the competent legal system along with the citizenship rights to select a lawyer to adjudication.

The principle of wayward arrest and the forbiddance of disrespect of the suspects is one of the most significant issues to observe the dignity of the citizens and their rights and freedoms (Shamse Nateri and Attarzade, 2009). Principle 32 of the constitution has predicted this right for the suspects, and policy 39 has predicted this right for those who have not been judged yet. But they have been arrested, according to the legal ruling or stay in detention besides that (Hashemi Shahrudi, 2007, 54). This law was without a certain administrative guarantee until 2015. Fortunately, this weakness was improved in the penal trial regulations so that the article 7 of this law considered the violation of any of the rules mentioned in the article 570 of the Islamic punishment law (punishments) unless stricter penalties are regarded in other rules. The subject of protection of the citizens of illegal pressure and the violation is related to the forbiddance of disrespect, and lack of attention to it is one of the most important goals of the rules that make the legal justice (Ashuri, 1990,143) disrupted. In this respect, the principle 38 of the constitution inflicting any tortures to get a confession or information is forbidden, and the penal system of Iran by the criminalization of it has supported it.

Paragraph 93 of the Charter to create an optimal balance between the benefits of the society and the sufferer and the suspects that are the most significant goal of the penal trial regulation (Ashuri, 1990, 37; Khaleghi, 2015, 15; Madani, 2001, 4) has obliged the state to create proper facilities. Solely, this ruling lacks a background in the regulations.

Finally the charter by the decision of "LaZarar" in paragraph 90 states that: <no-one can impose his right as a means of inflicting damage to the rights of the public $>$. As it is evident the main difference between this paragraph and other paragraphs is the non-state orientation of it an issue that should be considered in charters of the citizenship rights as a basis (Amirarjmand, 2006, 10) but its instances are less visible in the charter of the citizenship rights of Iran. As it is the right of the citizens to impose their rights and do not get violated by other citizens mutually they are responsible for acting in accord with others' rights and do not violate them even when they are against the imposition of their rights. This right has also been present in previous rules concerning the prediction of charter about the acceptance of the legal system of Iran. 
As it is evident whatever predicted in the letter regarding the legal rights instances, mostly have a legislative background in the legal system of Iran. And in most cases what has been predicted in the letter is even more deficient than what existed in the previous rules. It is also evident that the charter has not recognized the legal rights instances while these cases are the main principles of the legal rights issue.

The principle 36 of the constitution has predicted the legality of the crimes and the punishments by considering the significance of this issue within the penal system this principle in a broader sense, so that it generalizes the criminalization aspect as well in Article 13 of the Islamic punishment has been predicted. In fact, the Islamic punishment law has identified the legality of the criminal event as a broader principle that the principle of the lawfulness of the crimes and punishments (Khaleghi 2015, 10) within the penal law of Iran.

The open court principle within the legal system of Iran has been confirmed in principle 165 of the constitution. Given the sensitivity of the imposition of this right of the political and press-related cases, the first reinforcement of this law has been emphasized in the principle 168 of the constitution. The content of this policy has also been stressed in the formative rules such as the penal trail regulations.

Generally and regardless of the deficiencies that the legal system of Iran suffers from regarding the legal rights there has been an optimal performance. In this s system in addition to the determination of the primary legal rights basis other instances have also been considered. Such cases are somehow in a relationship with the issues above in this respect. For example, the legal and penal rules all refer to the lack of generalization of the regulations to the previous issues before the verification unless in exceptional cases and when there is a personal punishment by the article 141 of the Islamic punishment law is an approved principle within the legal system of Iran. Similarly, the forbiddance of the disrespect towards the suspects has been predicted, according to the constitution even for the culprits and the penal rules have predicted required criminal guarantee for them.

But the charter of the citizenship rights regarding the legal rights has introduced no innovation. Even the charter has not been able to explicitly fulfill its goal of aggregation of the citizenship rights in paragraphs 2 of the article 1. The letter principally has judged the intended instances efficiently and regarding the underlying issue that has had a legislative background within the legislation of Iran has kept silent.

\subsection{The Weaknesses of the Charter Regarding Legal Rights by the Human Dignity}

The legal security and the important rights of that are the indispensable part of the honorable life of a human being. Observing these principles for the individuals and the ruling power creates a responsibility so that individuals have to follow and respect the material and spiritual rights of each other. The state is responsible for codifying the law and arranging the legal and official structures by the human dignity and honor create security for people to live with confidence along with their honor. And secondly, they in observing the law, respect the rights of people and do not violate them waywardly $>$ (Hashemi, 2005, 276) all of the instances of the legal rights aggregate around this fundamental goal.

The charter of the citizenship rights regarding the legal rights has not considered the human dignity as the goal, but this does not mean that the charter lacks any positive point in this respect. The letter regarding the access to the competent legal system whose violation can lead to the disruption of the human dignity (Razavi and Seyyed Khazaie, 2010) has acted optimally. Regarding this basic focus, the charter by identifying the right of selecting a lawyer for the citizens and lack of considering an exemption for that (either the rightful or the subject that is verified by the legal authorities) has optimally identified this right for the citizens. Also assigning the pressure of the lower cost to the state is a positive point of the charter in this respect and assigning the rights above to the citizens with any language, race, religion or any condition. Also, no limitations concerning the features mentioned above show the restriction of the charter to observe the citizenship rights along with the human dignity. With these characteristics, there is no case of violating the human dignity.

Regarding the innocence principle the state is as follows: The charter by considering the particular position of the simplicity principle in penal affairs has predicted in an almost the same way done by the constitution. The emphasis on this issue should also be considered as a real problem in accord with the human dignity.

The charter of the citizenship rights regarding the wayward arrest and also the forbiddance of the disrespect of the suspects and the immunity of the citizens have judged the generality of this ruling. Although these issues in the charter have been stated as a general rule and can be criticized regarding the lack of attention to the details on the mentioned issues, the case that violates the human dignity through the restriction of the length of the inclusion of these principles cannot be observed. In fact, the criticism of the charter regarding the lack of considering the particular instance, about the forbiddance of disrespect of the suspects and the citizens is a structural deficiency and does not refer to the violation of the human dignity or the ignorance of the charter in 
this respect.

Given the explanations above that in some the legal rights that the Charter has entered the deficiency that originates from the lack of attention to the human dignity do not exist, but as it was mentioned earlier generally, the letter has not acted in accord with the human dignity. The weakness of the charter within the legal rights which has destabilized the position of the human dignity can be analyzed from two aspects: the first aspect is the widespread deficiencies. These shortcomings have troubled the post of the human dignity in the face of instances of the citizenship rights in the charter and consequently the legal rights. The most important issue in this respect is the position taken by the charter regarding the definition of the citizen. As mentioned earlier concerning the definition of the citizen there is a difference of view (Ghazi Shariat Panahi, 1994, 56; Miller 2004, 130) and the charter has not adopted the right view in accord with the human dignity.

Lack of the differentiation and separation between the citizenship rights and other similar rights, particularly the human rights has doubled the influence of the inapposite view of the citizen to the charter. Regardless of the differences of views regarding the relationship between the human rights and the citizenship rights that exist (Ghorbanzade, 2006, 29). Also, regardless of the criteria introduced to differentiate them from each other (Amirarjmand, 2006, 10). The Charter has placed the most evident instances of the human rights below the citizenship rights and regarding the rightful has considered merely the residents. The result of that is that non-Iranians are bereft of the citizenship rights and the related human dignity instances. This deficiency is present in all cases of the citizenship rights as well as the legal rights situations.

The other weakness of the charter regarding the legal rights that originate from the generality of the letter and can be observed in other instances of the citizenship rights is the lack of providing the intended definitions. For the example mentioned in paragraphs, $85-93$ is a general description that without a precise definition would not be interpreted and generalized in practice. Also, the lack of taking action regarding clarifying the issue with the legislative background in Iran, but because of the ambiguities that existed in it facilitated the violation of human dignity which is another weak point present in the charter. There are also some other general criticisms such as the lack of observing the ruling criteria on the codification of the citizenship rights (Dadandish et al., 2013, 120). Lack of benefiting from a reliable and secure framework and similar issues also exist that have affected the generality of the charter and diverting from the supreme goals of the charter.

The second aspect originates from the identity and the stating the legal rights. The weakness of the letter regarding the legal rights is the silence and lack of expressing an explicit position about some of the legal rights instances that their nature is so that they facilitate the violation of the human dignity and the lack of reference to them can somehow lead to this deficiency. One of the primary instances of the silence of the legal rights is the lack of retrospection principle, the legal principle of without crimes and punishments are more generally the legality of the criminal phenomena, the principle of personal penalties and the open courts. This subject, regardless of the subsidiary rights such as the last defense or the right of silence that the citizens should have during the judicial trial process. Indeed, what has been stated in paragraph 6 of the article 1 of the charter refers to that the letter did not make an attempt to create new rights and responsibilities or the development or the underdevelopment of them. And it is only a statement of the most significant citizenship rights cannot be inferred as the weak performance of the charter in identifying and attending the instances of the legal rights. Because the charter should have at least categorized and counted the cases of this issue.

One of the key areas regarding the previous rules that do not have a linear direction is the principle of forbiddance of inflicting violent and inhuman punishments for the citizens. But some have interpreted this from the constitution in an indirect way (Rahiminejad and Habibzade, 2008). This right that directly originates from the natural and intrinsic benevolence and honor in many of the international and regional and national documents have been identified the main reason of the incongruent punishments is their incongruity with the natural human dignity. The suspect and the culprit have respect. This issue is kept silent in the charter. Despite the significance of the principle of the incongruent punishments, none of the documents and rules and regulations about the human rights the incongruent sentences have not been defined. And no criterion and precise basis have been established to determine the crime and the punishment to estimate the proportionate penalties (Dirk Van and Ashworth, 2004, 546; Zarei, 1996, 245, Gase, 2000). It should be considered that some of the greatest punishments originate from Islam, and in this group of crimes, although the non-religious human dignity cannot justify the eligibility regarding ruling principle there is no way out of it. It seems that applying these violent punishments are not against the human dignity. But sometimes it appears that the legislator has overstepped in this field and predicted violent punishments in cases where there is no need for such a measure. For example the crimes related to drugs and the military forces. In these cases, the reviving of the dignity and respect and human dignity and revision of the present rules call for rectification. But unfortunately, the charter has taken measures in 
this regard and has taken no approach to implementing human dignity regarding legal rights.

\section{Conclusion}

- Given the preface and the general rules mentioned in the charter refer to the fact that human dignity in this document from the codifiers' vantage point has been the most significant criteria of arrangement. But in the first step, there has been a backward step from the goal of not providing the opposite atmosphere to respect and observe the human dignity.

- The charter of the legal right field has no innovation or creation in proportion to what existed in the legal system of Iran. The strength of the letter is the retelling of the principles previously present in the legislative background of Iran.

- The weaknesses of the charter are more than strengths of it. Regarding the legal rights, most of the shortcomings to the letter have lead to the violation of the human dignity. These rights can be analyzed at two levels of general and extraordinary to legal rights the first standards of the deficiencies have to cause the instability of the position of human dignity in all instances of the citizenship rights. Silence and lack of quick positioning towards the accepted principle in legal rights or the brevity of the predicted cases has also affected the result in particular regarding legal rights.

- The most significant deficiency of the charter is the inclusion of the criterion of residence in determining the number of the included people mentioned in the letter. In this document, the citizen is equal to the resident, and this is one of the primary deficiencies of the charter that leads to the violation of the human dignity through the shortage of the range of the legal rights inclusion towards the people. Besides that, the mingling of the human rights issues with that of the citizenship rights has intensified the problem.

- The charter has not predicted some significant instances and the legal rights such as the legality of the crimes and punishments or the personified principle of the penalties. This weakness can be considered as a primary deficiency of the charter and a violation of the human dignity. This gap in cases where the related principle has a legislative background causes less practical impact but in cases such as the principle of imposing the violent and inhuman punishments towards the citizens by considering the lack of legal history, it expected that the charter would present an approach in accord with human dignity but this has not been conducted.

\section{References}

Abunasre, F. (2002). Ara Ahlalmadine Alfasele daro maktube alhelal Beirut.

Akhavan, A. (n.d.). Resaelo Akhavan Alsaf. Dar sader, Beirut.

Akhundi, M. (2001). Penal trial regulations (Vol. 1). Islamic guidance and culture ministry Tehran.

Amirarjmand, A. (2006). Citizenship rights principles and human rights national trust, No.188, pp. 20-23.

Aramesh, K. (2011). Human dignity in biomedical ethics. medical journal of history and ethics in Iran, 3(3), 37-53.

Ashuri, M. (1990). Penal justice. Ganje danesh plibrary Tehran.

Azar dad, L. (2010). Citizenship rights at quasi judicial authorities. Jangal publications, Tehran.

Dadandish, P., Amini, A., Abadi, A., \& Kananian, S. (2013). challenges of the citizenship charter in Iran an emphasis on the article 100 of the program law development program four approach seasonal year 22 No. 68 , pp.255-287.

Dehkhoda Ali, A. (1998). Dictionary (Vol. 11). Tehran University Publications, Tehran.

Dirk Van, Z. S., \& Ashworth, A. (2004). Disproportionate Sentences as Human Rights violations. The Modern law Review, 67(4).

Ebne, K. (n.d.). preface to Ebne khaldun (Vol. 1). translated by Muhammad Parvin Gonabadi translation company and book publication Tehran.

Ebne manzur Jamaledin Muhammad ebne Mokram. (1983). Lesanolarab (Vol. 12). Qom hoze adabo nashr.

Etedal, M. (1998). Penal trial regulation in Iranian legal modern system Navid publication Shiraz.

Falks, H. (2002). citizenship translated by Muhammad taghi A.

Farhidi Khalileben, A. (1988). Alein (Vol. 5). Darolhejre publication. 
Gase, R. (2000). Is there a crime? Translated by Ali Hussein Najafi Abarandabadi Shahid Beheshti University No.29 and 30 PP.45-64

Ghari seyyed Fatemi, S. M. (2003). Human rights in the modern world (Vol. 1). Beheshti University Publication Tehran.

Ghazi Shariat Panahi, A. (1996). requirements of the constitution Dadgostar publication Tehran.

Ghorbanzade, H. (2006). Citizenship rights protection under ruling principles on fair trial M.A. criminology law Imam Sadigh University criminology and law department.

Hashemi Seyyed, M. (2005). Islamic Republic of Iran law (Vol. 1). Mizan publication Tehran.

Hashemi Shahrudi, S. M. (2007). Citizenship and justice doctrine of the Ayatollah Hashemi Shahrudi selected articles of the citizenship rights center of the press and publication Tehran.

Hashemiyan Far, S. A., \& Ganji, M. (2007). an analysis of the citizenship culture in Isfahan city practical sociology twentieth year consecutive number 33 No.1 pp.25-44.

Hezar jaribi, J., \& Safari Shali, R. (2010). analysis of the interaction of two concepts of citizenship and social security and order and security of the society third year No.3 pp.157-184.

Hosseini Dashti, S. M. (2006). knowledge and cognition of comprehensive Islamic encyclopedia (Vol. 2). Arayeh cultural institute Tehran.

Hosseini Shah Abdolazimi, H. E. A. (1987). Esna Ashari Tafsi Mighat publication Tehran.

Kamyar, G. (2000). Citizenship rights Majd publication Tehran.

Kant, I. (1956). Critique of Practical Reason, tr: Beck, L.w.Newyork, The Library of Liberal Arts.

Kastelz and Davidson, Alister. (2003). Migration and citizenship translated by Taghilu strategic studies research center Tehran.

Katuzian, N. (2000). A preface to law science. Enteshar company Tehran.

Katuzian, N. (2006). Law philosophy (Vol. 1). Enteshar company Tehran.

Khaje nasiroddin Tusi. (1984). Naseri ethics, editied by Mojtaba Minavi Alireza Heidar Kharazmi Tehran.

Khalegi, A. (2015). penal trial regulations (Vol. 1). Shahre danesh publication Tehran.

Kinia, M. (1972). basic principles of law. Tehran University Publications.

Madani, S. J. (2001). penal trail regulation 1, 2 Paydar publications Tehran.

Madaniyan, G. (2011). an article on the concept and definition of citizenship. Tehran University Qom Pardis of law faculty.

Makarem, S. N. (1997). Tafsire Nemune (Vol. 14). Draolketab aleslamiye Tehran.

Miller, D. (2004). human rights and citizenship responsible to limitation. strategic seasonal, (23), 128-149.

Mohseni, F. (2007). criminal political dialogue of the legislator in the law respect of eligible freedom and protection of citizenship rights passed in 2004) selected articles of the citizenship conference) judiciary power publication Tehran.

Muhammad Rezaie, M. (2000). statement and criticism of the ethics philosophy of Kant Book park Qom.

Musavi Hamadani, Seyyed Muhammad Bagher. (1996). translation of almizan tafsir V.1 Islamic publication society of Hoze instructors Qom.

NnamaniOgbu, O. (2005). Punishmants in Islamic Criminal law as Antithetical to Human Dignity: The Nigerian

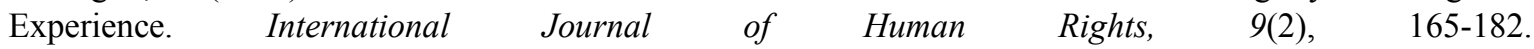
https://doi.org/10.1080/13642980500095302

Pallu, R. (1991). citizen and state, translated by abolfazl gazi Daneshgah Publication Tehran.

Pollitt, C. (1994). The Citizen's Charter: A Preliminary Analysis. Public Money \&Management, 14(2). https://doi.org/10.1080/09540969409387809

Pur ezzat, A. A., Huriye, B. B., \& Mostafa Nejati, A. (2008). rational charter of the pattern of citizenship rights on the basis of the adaptation of the present documents social research seasonal seventh year No.26 pp131-160.

Rahimi Nejad, E. (1999). human dignity in penal law. Mizan publication Tehran. 
Rahiminejad, E., \& Habibzade, M. J. (2008). inapposite punishments. Incommensurate punishments with the human dignity law seasonal journal law faculty and political science period 38 No.2, PP115-133.

Razavi, M., \& S, K. (2010). citizenship rights in the criminology process regularity science seasonal journal, ninths year No fourth pp.85-107.

Sadr Seyyed Muhammad Bagher. (2002). historic traditions in Quran, translated by Seyyed Muhammad Jamaledin Musavi Esfehani Tafahim publication Tehran.

Shams Nateri, M. E., \& Attarzade, S. (2009). penal support of the citizenship rights in Iran detective, second round, No.4 pp.66-82.

Shayegan Seyyed Ali. (1956). civil law of Iran. Tehran.

Short Oxford English Dictionary, Fifth Editation, vol 1, Oxford University Press, 2002.

Tabarsi Aminoleslam. (1992). Majmaolbayan fi tafsi al Quran Naserkhosro Tehran.

Tavakkol Muhammad. (2003). cognition sociology. Qom University and Hoze research center.

Tayyebi, H. (1999). principles of sociology Islamiye bookshop Tehranfruz Kavir publication Tehran.

Zarei, H. (1996). the proportion between crime and punishment M.A. thesis

\section{Copyrights}

Copyright for this article is retained by the author(s), with first publication rights granted to the journal.

This is an open-access article distributed under the terms and conditions of the Creative Commons Attribution license (http://creativecommons.org/licenses/by/4.0/). 